\title{
Somatic and germline mutation in GRIM-19, a dual function gene involved in mitochondrial metabolism and cell death, is linked to mitochondrion-rich (Hürthle cell) tumours of the thyroid
}

\section{Máximo', T Botelho', J Capela ${ }^{2}$, P Soares ${ }^{1,3}$, J Lima', A Taveira ${ }^{1,2}$, T Amaro ${ }^{4}$, AP Barbosa ${ }^{5}$, A Preto', HR Harach ${ }^{6}$, D Williams ${ }^{7}$ and M Sobrinho-Simões*,1,3,8}

IIPATIMUP-Institute of Molecular Pathology and Immunology of the University of Porto, Rua Dr Roberto Frias s/n, 4200-465 Porto, Portugal; ${ }^{2}$ Department of Surgery, Hospital São João, Porto, Portugal; ${ }^{3}$ Department of Pathology, Medical Faculty of Porto, Porto, Portugal; ${ }^{4}$ Department of Pathology, Portuguese Oncology Institute, Porto, Portugal; ${ }^{5}$ Department of Endocrinology, Portuguese Oncology Institute, Porto, Portugal; 'Pathology Senvice, 'Dr A Onãtivia' Hospital, Salta, Argentina; ${ }^{7}$ Strangeways Research Laboratory, University of Cambridge, Cambridge, UK; ${ }^{8}$ Department of Pathology, Hospital São João, Porto, Portugal

\begin{abstract}
Oxyphil or Hürthle cell tumours of the thyroid are characterised by their consistent excessive number of mitochondria. A recently discovered gene, GRIM- 19 has been found to fulfil two roles within the cell: as a member of the interferon- $\beta$ and retinoic acid-induced pathway of cell death, and as part of the mitochondrial Complex I assembly. In addition, a gene predisposing to thyroid tumours with cell oxyphilia (TCO) has been mapped to chromosome 19p/3.2 in one family. A cluster of genes involved in mitochondrial metabolism occurs in this region; one of these is GRIM-19. We have searched for GRIM-19 mutations in a series of 52 thyroid tumours. Somatic missense mutations in GRIM-19 were detected in three of 20 sporadic Hürthle cell carcinomas. A germline mutation was detected in a Hürthle cell papillary carcinoma arising in a thyroid with multiple Hürthle cell nodules. No mutations were detected in any of the 20 non-Hürthle cell carcinomas tested, nor in any of 96 blood donor samples. In one of the sporadic Hürthle cell papillary carcinomas positive for GRIM- 19 mutation, we have also detected a ret/PTC-I rearrangement. No GRIM- 19 mutations were detected in any of the six cases of known familial Hürthle cell tumour tested, so that our results do not support the identification of GRIM- 19 as the TCO gene. The GRIM- 19 mutations we have detected are the first nuclear gene mutations specific to Hürthle cell tumours to be reported to date; we propose that such mutations can be involved in the genesis of sporadic or familial Hürthle cell tumours through the dual function of GRIM-19 in mitochondrial metabolism and cell death.

British Journal of Cancer (2005) 92, I892- |898. doi:I0.1038/sj.bjc.6602547 www.bjcancer.com
\end{abstract}

Published online 19 April 2005

(c) 2005 Cancer Research UK

Keywords: thyroid cancer; familial thyroid carcinoma; Hürthle cell tumours; GRIM-19; mitochondrial proteins

Oxyphil or Hürthle cell thyroid tumours constitute an unusual form of neoplasm composed of cells with a great increase in mitochondrial number, corresponding morphologically to their voluminous, granular, eosinophilic cytoplasm (Hamperl, 1962; Nesland et al, 1985; Sobrinho-Simões et al, 1985; Rosai et al, 1992; Sobrinho-Simões, 1995). The excessive numbers of mitochondria are found in all tumour cells, both in adenomas and in carcinomas. Large deletions of mitochondrial DNA (mtDNA), as well as somatic mutations of some mitochondrial genes are the hallmark of Hürthle cell tumours (Máximo and Sobrinho-Simões, 2000a; Máximo et al, 2002). Hürthle cell tumours are multiple in a proportion of cases; the multiple tumours more often occur in younger patients than the solitary tumours, suggesting a germline

*Correspondence: Dr M Sobrinho-Simões, IPATIMUP-Institute of Molecular Pathology and Immunology of the University of Porto, Rua Dr Roberto Frias s/n, 4200-465 Porto, Portugal;

E-mail: ssimoes@ipatimup.pt

Received 23 November 2004; revised 18 February 2005; accepted 28 February 2005; published online 19 April 2005 defect (Katoh et al, 1998). Dominant inheritance has only rarely been reported; a study of one pedigree with familial Hürthle cell tumours found a linkage to chromosome 19p13.2, but the identity and function of this TCO gene remains unknown (Canzian et al, 1998).

Recently, a novel gene, GRIM-19, has been identified. It is one of several genes associated with retinoid-interferon-induced mortality (GRIM) that have been reported in the literature (Hofmann et al, 1998). GRIM-19 is a cell death regulatory gene that promotes apoptosis, is a negative regulator of cell growth and is also involved in mitochondrial metabolism (Angell et al, 2000; Lufei et al, 2003), it has been mapped to human chromosome 19p13.2 (Chidambaram et al, 2000). GRIM-19 is the human homologue of the bovine subunit of the mitochondrial NADH:ubiquinone oxireductase complex (Complex I) of the mitochondrial respiratory chain (MRC) (Fearnley et al, 2001). Like cytochrome $c$, which has a role in the induction of the cell's apoptotic programme and in the MRC (Liu et al, 1996), and endonuclease G, which is released from mitochondria during apoptosis and subsequently translocated to the nucleus (Li et al, 2001), GRIM-19 has been found to fulfil two roles within the cell: as a member of the interferon- $\beta$ and 
retinoic acid-induced pathway of cell death (Angell et al, 2000), and as part of the mitochondrial Complex I assembly (Fearnley et al, 2001). These two seemingly disparate functions may be linked, through the involvement of mitochondria in apoptotic cell death.

The functional importance of GRIM-19 has been recently highlighted by knockout experiments. Huang et al (2004) generated mice deficient in GRIM-19 by gene targeting, and showed that homologous deletion of GRIM-19 causes embryonic lethality at embryonic day 9.5. Interestingly, GRIM-19 $9^{-1-}$ blastocysts display abnormal mitochondrial structure, morphology and cellular distribution (Huang et al, 2004).

The consistent linkage of increased mitochondrial number and increased cell growth that characterises Hürthle cell tumours suggests that one gene could be involved in both features. The dual role of GRIM-19 in apoptosis and mitochondrial biogenesis makes it a good candidate for being a gene involved in Hürthle cell tumorigenesis. Its localisation to the same region as the TCO gene (chromosome 19p13.2) also suggested that it could be involved in the aetiopathogenesis of familial Hürthle cell tumours. We have therefore searched for GRIM-19 mutations in Hürthle cell tumours, and in controls.

Lufei et al (2003) and Zhang et al (2003) have demonstrated that the major role of GRIM-19 in control of cell growth is exerted through STAT3, a transcription factor known to be inhibited by GRIM-19 binding (Lufei et al, 2003; Zhang et al, 2003). Signal transducers and activators of transcription (STATs) are a family of latent cytoplasmic transcription factors that are activated after recruitment by the cytokine membrane receptors and subsequent phosphorylation. STAT proteins form homo- or heterodimers by reciprocal interactions between $\mathrm{SH} 2$ domains and phosphorylated tyrosine residues, translocate to the nucleus, bind to DNA and regulate their target gene expression (Darnell et al, 1994). It was suggested that activation of STAT3 may contribute to the loss of cell growth control, therefore leading to carcinogenesis (Grandis et al, 2000), by inducing elevated expression of genes involved in controlling fundamental cellular processes such as cyclin D1 (Fukada et al, 1998), c-Myc (Bromberg et al, 1999), p21 WAF1/CIP1 (Chin et al, 1996), as well as VEGF (Niu et al, 2002) and ICAM1 (Caldenhoven et al, 1996; Cantwell et al, 1998; Hwang et al, 2003). Owing to the difficulty in studying the functional impairment of mutated GRIM-19 directly in formalin-fixed tissue, we have investigated the levels of expression of ICAM1 in our series in an attempt to provide indirect evidence of the putative loss of function of GRIM-19.

Since ret/PTC rearrangements and $B-R A F$ mutations are particularly prevalent in papillary carcinomas regardless of whether or not they have Hürthle cell features (Grieco et al, 1990; Soares et al, 1998, 2003; Sugg et al, 1998; Cohen et al, 2003; Kimura et al, 2003), we have also searched for the aforementioned genetic alterations in Hürthle cell carcinomas with GRIM-19 mutations.

\section{MATERIALS AND METHODS}

\section{Material}

We studied 26 sporadic Hürthle cell tumours (five adenomas, 11 cases of the Hürthle cell variant of follicular carcinoma and 10 cases of the Hürthle cell variant of papillary carcinoma, all showing papillary carcinoma nuclear features), six carcinomas from two families with Hürthle cell tumours, 20 cases of non-Hürthle cell carcinomas (10 follicular carcinomas and 10 papillary carcinomas) (DeLellis et al, 2004) and 96 blood donor samples. In one of the families (four cases) there was known linkage to chromosome 19p13.2. The study was approved by the Ethical Committees of all Institutions involved and informed consent was obtained from all individuals studied.

\section{DNA extraction}

DNA was extracted from microdissected frozen and/or paraffinembedded tissue pairs (tumour and adjacent 'normal' thyroid) using the NucleoSpin ${ }^{\circledR}$ Tissue Kit (Macherey-Nagel, Düren, Germany). DNA from blood of some patients and from blood donor samples was also extracted using the same procedure.

\section{Screening of GRIM-19 mutations}

We searched for mutations in all five exons of GRIM-19 including intronic boundaries (primer sequences shown in Table 1) using PCR/Automated sequencing. All PCR amplifications were performed in a $25 \mu \mathrm{l}$ volume containing $200 \mu \mathrm{m}$ of each dNTP, $12.5 \mathrm{pmol}$ of each of the forward and reverse primers, $50 \mathrm{mM} \mathrm{KCl}$, $10 \mathrm{~mm}$ Tris- $\mathrm{HCl}$ ( $\mathrm{pH} 9.0$ ), $1.5 \mathrm{~mm} \mathrm{MgCl}_{2}$ and $1 \mathrm{U}$ of Taq DNA polymerase (Amersham Pharmacia Biotech). Cycling conditions were a single predenaturation step at $94^{\circ} \mathrm{C}$ for $5 \mathrm{~min}$ followed by 35 cycles of denaturation at $94^{\circ} \mathrm{C}$ for $20 \mathrm{~s}$, annealing at $60^{\circ} \mathrm{C}$ for $20 \mathrm{~s}$ and elongation at $72^{\circ} \mathrm{C}$ for $30 \mathrm{~s}$, and a final incubation at $72^{\circ} \mathrm{C}$ for $5 \mathrm{~min}$. PCR products were separated by electrophoresis on $2 \%$ agarose gels and purified using the NucleoSpin ${ }^{\circledR}$ Extract Kit (Macherey-Nagel, Düren, Germany). Sequencing analysis was then carried out on purified products using the ABI Prism BigDye ${ }^{\mathrm{TM}}$ Terminator Ready Reaction Kit (Perkin-Elmer, Foster City, CA, USA) and an ABI prism 377 DNA sequencer (Perkin-Elmer). Both strands were screened using the original primers. All altered samples were subjected to an additional complete analysis.

\section{Loss of heterozygosity analysis}

Two markers (D19S916 and D19S413) located in the TCO (19p13.2) region were used for the loss of heterozygosity $(\mathrm{LOH})$ studies with $\left[{ }^{32} \mathrm{P}\right] \mathrm{dCTP}$ (Amersham, UK) radioactive PCR amplification. Cycling conditions were a single predenaturation step at $94^{\circ} \mathrm{C}$ for $5 \mathrm{~min}$ followed by 35 cycles of denaturation at $94^{\circ} \mathrm{C}$ for $20 \mathrm{~s}$, annealing at $58^{\circ} \mathrm{C}$ for $20 \mathrm{~s}$ and elongation at $72^{\circ} \mathrm{C}$ for $30 \mathrm{~s}$, and a final incubation at $72^{\circ} \mathrm{C}$ for $5 \mathrm{~min}$. Amplicons were separated on $6 \%$ polyacrylamide denaturing gels, and exposed to X-ray film at room temperature. Loss of heterozygosity was determined by comparing the intensity of the alleles in heterozygosity samples of matched tumour and normal DNA. Loss of heterozygosity analysis was performed in all cases of sporadic $(n=26)$ Hürthle cell tumours.

Table I Primer sequences used in GRIM-19 amplification and sequencing

\begin{tabular}{ll}
\hline & Primer sequence $\mathbf{( 5}^{\prime} \mathbf{- 3}^{\prime} \mathbf{~}^{\mathbf{a}}$ \\
\hline Exon-1 & GCA ACA CCC CAG AGG CAA GGT GA \\
& AGA CTC TGA GAC CCC GGC GCA \\
Exon-2 & CAG TGT CCC CTG ATT GCA GAC \\
& ACT TTC AGA CAA CGC CCA CCA \\
Exon-3 & GGT CTG ACC TGA GTG TGG GT \\
& CTT CCG GCC AGT GAC CTC CCA \\
Exon-4 & AGG CTT GAA GGG GTG CTA CTA \\
& TCT GCC GTG GCT GGC ACC TCT \\
Exon-5 & GGT GGC TGT GCC TCT ACC CAT \\
& AAA GGG GGT CAG GGG TCC TTT
\end{tabular}

a For each exon, the first oligonucleotide represents the forward primer, and the second corresponds to the reverse primer. 


\section{Evaluation of the expression of ICAM1}

To obtain an indirect evaluation of the functional activity of GRIM-19, we calculated the relative expression of ICAM1 (tumour tissue $v s$ normal adjacent tissue) in 26 Hürthle cell tumours with and without GRIM-19 mutations. ICAM1 is known to be upregulated by STAT3, a transcription factor whose function is inhibited by GRIM-19 protein (Lufei et al, 2003; Zhang et al, 2003). ICAM1 expression was performed as follows. For each sample $1.0 \mu \mathrm{g}$ of RNA was reverse transcribed in a reaction volume of $20 \mu \mathrm{l}$ in the presence of $4 \mathrm{~mm} \mathrm{dNTP}, 1.0 \mathrm{U} \mu \mathrm{l}^{-1}$ RNase inhibitor, $2.5 \mu \mathrm{M}$ random primer $\mathrm{P}(\mathrm{dN})_{6}$ and $10 \mathrm{U} \mu \mathrm{l}^{-1} \mathrm{M}-\mathrm{MLV}$ reverse transcriptase. Reverse-transcribed cDNAs $(0.25 \mu \mathrm{g})$ from normal and neoplastic tissues were used to coamplify the housekeeping gene - glyceraldehyde-3-phosphate dehydrogenase (GAPDH) (primers GAPDHF - tgt cag tgg tgg gac ctg acc $\mathrm{t}$ - and GAPDHR - cac cct gtt gct gta gcc aaa tt; amplicon: $254 \mathrm{bp}$ ), and the differentially expressed gene - ICAM1 gene (primers ICAM1F - caa ccg gaa ggt gta tga act ga - and ICAM1R - tgg cag cgt agg gta agg ttc tt; amplicon: $186 \mathrm{bp}$ ). Cycling conditions were a single predenaturation step at $94{ }^{\circ} \mathrm{C}$ for $5 \mathrm{~min}$ followed by 24 cycles of denaturation at $94{ }^{\circ} \mathrm{C}$ for $20 \mathrm{~s}$, annealing at $58^{\circ} \mathrm{C}$ for $20 \mathrm{~s}$ and elongation at $72{ }^{\circ} \mathrm{C}$ for $20 \mathrm{~s}$, and a final incubation at $72{ }^{\circ} \mathrm{C}$ for $5 \mathrm{~min}$. The PCR products were separated in an agarose gel (2\%), and stained with ethidium bromide. The intensity of the fluorescence was automatically measured and integrated using the Multi-Analyst - version 1.1 software in the BIO RAD Gel DOC 1000 (BIO RAD, CA, USA). All the quantitations were performed in triplicate.

\section{Screening of ret/PTC rearrangements}

RNA extracted from paraffin-embedded tumour tissue of patients who presented GRIM-19 mutations was used for detecting ret/PTC rearrangements following the procedures previously described (Finn et al, 2003).

\section{Screening of $B-R A F$ mutations}

To screen for $B-R A F$ mutations, we analysed DNA extracted from paraffin-embedded tumour tissue and adjacent thyroid tissue of patients who presented GRIM-19 mutations following the procedures previously described (Davies et al, 2002; Soares et al, 2003).

\section{Statistical analysis}

The statistical analysis of the results was performed using $\chi^{2}$ test with the Yates correction, Fisher's exact test and Student's $t$-test. A $P$-value of $<0.05$ was considered statistically significant.

\section{RESULTS}

\section{Screening of GRIM-19 mutations}

The results of GRIM-19 analysis are summarized in Table 2 and Figure 1. Sequence determination of the five exons of GRIM-19 in the 26 apparently sporadic Hürthle cell tumours disclosed the existence of four mutations: a $\mathrm{C} \rightarrow \mathrm{T}$ substitution at nucleotide 77 (exon 1) resulting in an alanine-to-valine change at residue 26 in patient 4 (Hürthle cell variant of follicular carcinoma); a $\mathrm{G} \rightarrow \mathrm{C}$ substitution at nucleotide 264 resulting in a lysine-to-asparagine change at residue 88 (exon 1) in patient 5 (Hürthle cell variant of papillary carcinoma with Warthin's like features) (Figure 1); an $\mathrm{A} \rightarrow \mathrm{G}$ substitution at nucleotide 247 resulting in a serine-toglycine change at residue 83 (exon 1 ) in patient 6 (Hürthle cell variant of papillary carcinoma); and a $\mathrm{G} \rightarrow \mathrm{C}$ substitution at nucleotide 593 resulting in a arginine-to-proline change at residue 198 (exon 5) in patient 7 (Hürthle cell variant of papillary carcinoma). All mutations detected were heterozygous.
Table 2 Summary of the data on the four cases with GRIM- 19 mutations

\begin{tabular}{lclll}
\hline Case & $\begin{array}{c}\text { Age } \\
\text { (years) }\end{array}$ & Diagnosis & $\begin{array}{l}\text { Nucleotide } \\
\text { alteration }\end{array}$ & $\begin{array}{l}\text { Protein } \\
\text { alteration }\end{array}$ \\
\hline 4 & 42 & HCFC & C77T & A26V \\
5 & 60 & HCPC & G264C & K88N \\
6 & 33 & HCPC & A247G & S83G \\
7 & 32 & HCPC & G593C & R198P \\
\hline
\end{tabular}

HCFC $=$ Hürthle cell variant of follicular carcinoma, $\mathrm{HCPC}=$ Hürthle cell variant of papillary carcinoma.

In patient 5, the thyroid tissue apart from the papillary carcinoma was almost totally occupied by several nodules composed of Hürthle cells; in all samples tested, including the carcinoma, one benign nodule and the internodular normal tissue, we detected the same mutation $(\mathrm{a} \mathrm{G} \rightarrow \mathrm{C}$ substitution at nucleotide 264 resulting in a lysine-to-asparagine change at residue 88 ). The same mutation was also detected in the peripheral blood of the patient thus confirming its germline nature. The germline nature of the mutation was confirmed by its detection in the peripheral blood of one son, aged 41 years, with no clinical or ecographic signs of thyroid disease. The mutation was not detected in the other son nor in the daughter of the patient. No mutations were detected in the adjacent normal thyroid parenchyma of the other three cases with a GRIM-19 mutation (patients 4,6 and 7), nor in any of the 42 other normal thyroid samples.

We did not detect mutations in the GRIM-19 gene in any of the six cases of known familial Hürthle cell tumours, in any of the 20 cases of non-Hürthle follicular and papillary carcinomas, nor in any of the 96 blood donor samples. The frequency of GRIM-19 somatic mutations in the cases of Hürthle cell variant of follicular carcinoma (one out of $11 ; 9.1 \%$ ) is not statistically different from the frequency of GRIM-19 somatic mutations in cases of Hürthle cell variant of papillary carcinoma (two out of 10; $20.0 \%)(P=0.476)$; the same holds true if the case presenting the GRIM-19 germline mutation is included (three out of 10 ; $30.0 \%)(P=0.223)$. None of the previously described polymorphisms (National Center for Biotechnology Information (http:// www.ncbi.nlm.nih.gov)) occurring at exonic regions were detected in these cases.

The presence of GRIM-19 mutations was not significantly associated with the age and/or gender of the patients (data not shown) nor with the histotype of the lesions other than the oxyphilia (Figure 2), including the presence or absence of lymphocytic thyroiditis. No significant association was also found between the presence of GRIM-19 mutations and the mtDNA somatic mutations detected in a previous study (Máximo et al, 2002) (data not shown).

\section{Loss of heterozygosity}

The 26 cases in which $\mathrm{LOH}$ analysis was performed were informative for at least one of the two markers. We did not find $\mathrm{LOH}$ in any of the four Hürthle cell tumours presenting GRIM-19 mutations, nor in any of the other 22 sporadic Hürthle cell tumours.

\section{Expression of ICAM1}

The results are summarized in Table 3. The four tumours with mutations had significantly $(P<0.001)$ higher levels of ICAM1 expression in tumoural tissue $v s$ normal tissue (range of the ratio between the expressions of ICAM1 in tumoural tissues vs normal tissue: $3.2-5.0$; mean \pm standard deviation $=3.9 \pm 0.8$ ) (Table 3) than the 22 cases without GRIM-19 mutation (range: 0.9-2.4; mean \pm standard deviation $=1.4 \pm 0.4$ ). Only two cases without 
A C A C C C GGCAGC G TAT T 70

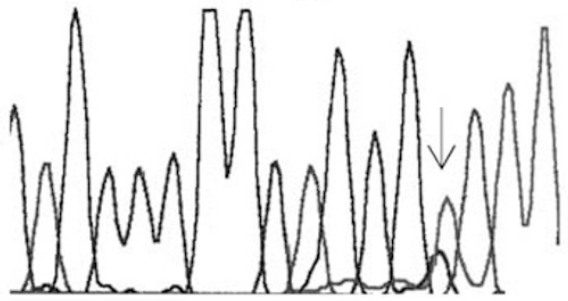

C GGCG T CAACG T A A CAGG $50 \quad 60$

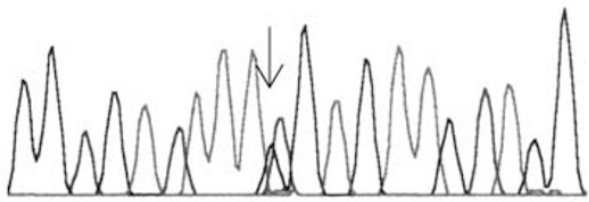

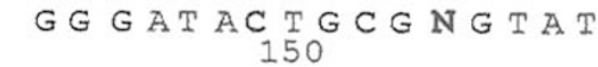

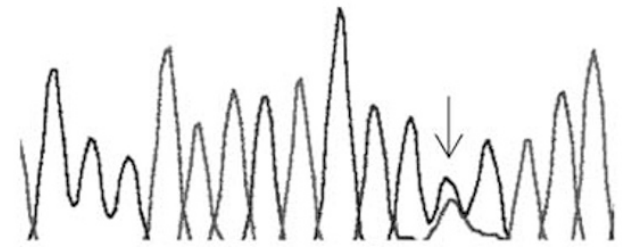

GCAAC C N N T G G T TC 110
B CA GCC G GCAGCGCAT T 80
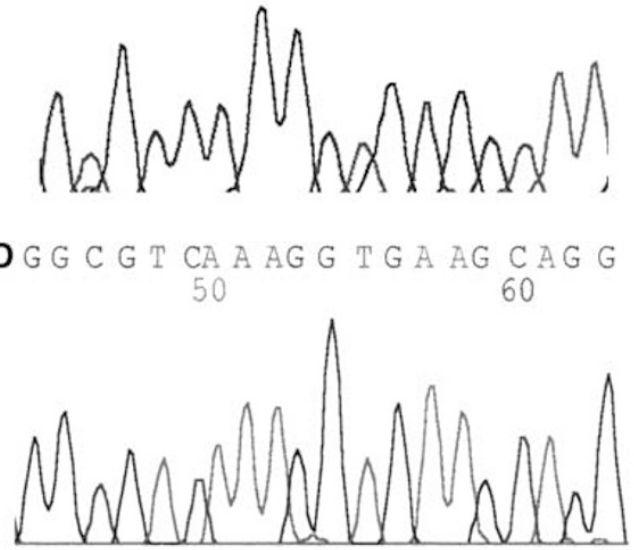

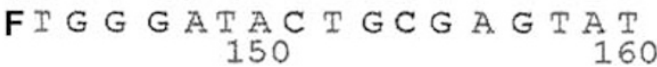

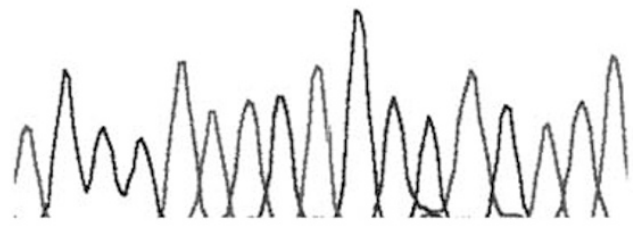

HCA AC C C G C T G G T GC
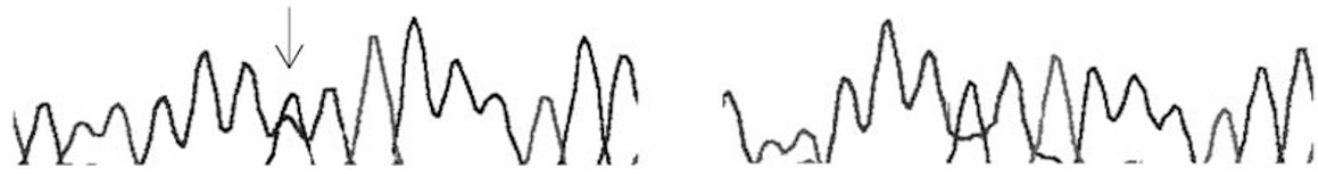

Figure I Electropherograms showing GRIM-19 mutations in case 4 (A - mutated sequence, B - wild-type sequence), case 5 (C - mutated sequence, D - wild-type sequence), case 6 (E - mutated sequence, $\mathbf{F}$ - wild-type sequence) and case 7 ( $\mathbf{G}$ - mutated sequence, $\mathbf{H}$ - wild-type sequence). The mutated nucleotides are indicated by the arrow. For details see Table 2 .

GRIM-19 mutation (case 12, HCPC and case 15, HCPC) showed a level of expression in tumoural tissue higher than 2 (2.3 and 2.4, respectively).

\section{Screening for RET/PTC rearrangements and $B-R A F$ mutations}

The data concerning the screening for RET/PTC rearrangements and $B-R A F$ mutations in cases displaying GRIM-19 mutation are summarized in Table 4 (case 6 - not studied for technical limitations). Ret/PTC-1 chimeric transcripts were detected in one case (Case 7); no ret/PTC-3 chimeric transcripts were detected in any case. No mutations in exons 11 and 15 of $B-R A F$ were detected in any of the three cases from which material was available.

\section{DISCUSSION}

The GRIM-19 mutations we have described are the first nuclear gene mutations specific to Hürthle cell tumours to be reported to date. The detection of GRIM-19 mutations in four of 26 apparently sporadic Hürthle cell tumours, and their absence in 20 nonHürthle cell tumours and 96 blood donors support the hypothesis that alterations of GRIM-19 are involved in the etiopathogenesis of these tumours. Further support comes from a search for germline mutations. While these were not found in the two known families studied, one germline mutation was found in the 142 samples tested (46 normal thyroids and 96 blood donor samples), and this occurred in the only apparently sporadic tumour with multiple Hürthle cell lesions. None of the alterations detected were previously described as polymorphisms, suggesting that might affect the function of the protein, or that they are rare polymorphisms. When we compare the amino-acid sequence of the protein GRIM-19 of four different species (Homo sapiens, Bos taurus, Mus musculus and Xenopus tropicalis), two of the mutations are located in phylogenetically conserved positions (K88N, case 5 and R198P, case 7) (Figure 3), suggesting that they might directly affect the function of the protein. The remaining mutations (A26V, case 4 and S83G, case 6) are located in a region of human GRIM-19 protein that has no correspondence to the 
1896

GRIM-19 of other species; human GRIM-19 is the largest of the four.

In contrast to the absence of other documented nuclear genetic alterations, several mtDNA alterations (including large deletions and somatic mutations) have been described in sporadic Hürthle cell tumours (Tallini et al, 1994; Máximo and Sobrinho-Simões,
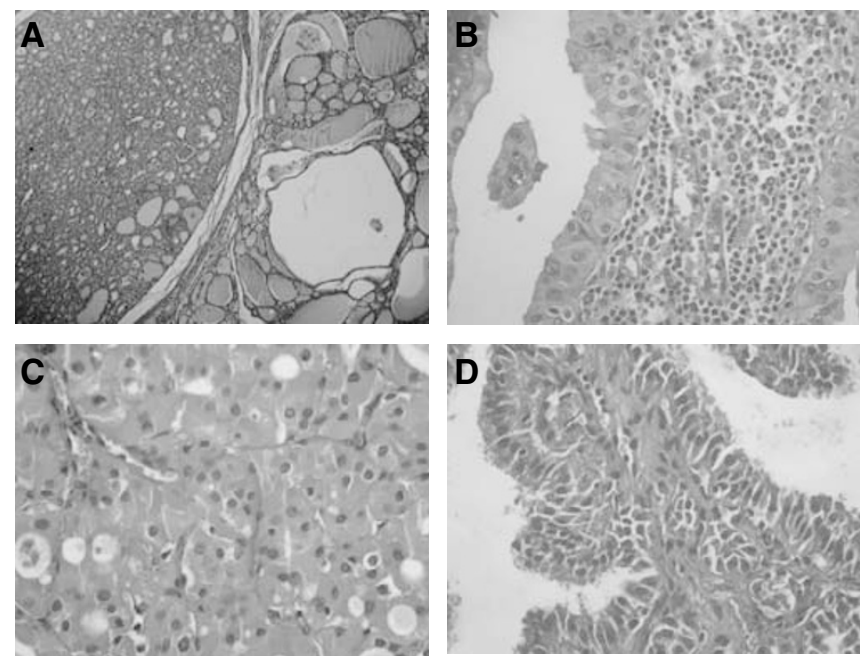

Figure 2 Histology of GRIM-19 mutated tumours. A and $\mathbf{B}$ - Hürthle cell lesions from case 5 presenting GRIM-19 germline mutations (A Hürthle cell adenoma; $\mathbf{B}$ - Hürthle cell variant of papillary carcinoma). (C) Hürthle cell variant of follicular carcinoma (case 4) displaying somatic GRIM- 19 mutation. (D) Hürthle cell variant of papillary carcinoma (case 7 ) presenting a somatic GRIM- 19 mutation and a ret/PTC-I rearrangement.

Table 3 Summary of the data on ICAM I relative expression in the four cases with GRIM-19 mutations

\begin{tabular}{lclc}
\hline Case & Age (years) & Diagnosis & $\begin{array}{c}\text { ICAMI expression }^{\mathbf{a}} \\
\text { Tumour tissue vs } \\
\text { normal tissue }\end{array}$ \\
\hline 4 & 42 & HCFC & $3.2 \pm 0.4$ \\
5 & 60 & HCPC & $4.1 \pm 0.1$ \\
6 & 33 & HCPC & $3.3 \pm 0.3$ \\
7 & 32 & HCPC & $5.0 \pm 0.3$
\end{tabular}

HCFC $=$ Hürthle cell variant of follicular carcinoma, $\mathrm{HCPC}=$ Hürthle cell variant of papillary carcinoma. ${ }^{2} V$ alues are expressed as the ratio between the expressions of ICAMI in tumoural tissues vs normal tissue, in mean \pm s.d. (after three measurements per case). 2000b; Máximo et al, 2002). Curiously, most of the somatic mutations of the mtDNA on record involve genes that, like GRIM19, code for components of Complex I of MRC (Yeh et al, 2000; Máximo et al, 2002). These genes are crucial for the oxidative phosphorylation process and consequently for the cell's energy production, and it has been suggested that mutations in genes directly or indirectly affecting mitochondrial function could be the cause of the increase in mitochondrial number in Hürthle cell tumours (Katoh et al, 1998). It is known that a defect in the energy production machinery of the cell can lead to a secondary increase in the number of mitochondria, through a feedback mechanism (Attardi et al, 1995). Loss of function of GRIM-19 can therefore explain the mitochondrial excess typical of Hürthle cell tumours.

Mutations in GRIM-19 as well as affecting mitochondrial number could also influence cell growth and apoptosis. This role of GRIM-19 was demonstrated using in vitro models by Angell et al (2000), who showed that overexpression of GRIM-19 enhanced cell death in MCF-7 cells, whereas its downregulation, as well as its deletion, provided growth advantage and decreased cell death (Angell et al, 2000). Huang et al (2004) confirmed that GRIM-19 protein cellular localisation in various cell types is primarily mitochondrial. Furthermore, GRIM-19 is detected in the native form of mitochondrial complex I and the elimination of GRIM-19 destroys the assembly and electron transfer activity of Complex I and also influences the other complexes in the mitochondrial respiratory chain (Huang et al, 2004).

In this study, GRIM-19 mutations were found in $16 \%$ of Hürthle cell tumours. However GRIM-19 is one of a number of genes that code for proteins involved in mitochondrial electron transport. Clusters of these genes occur at 19p13.2 (http://www.ncbi.nlm. nih.gov) and at 17p13 (Farrand et al, 2002), both regions of the genome linked to Hürthle cell tumours. It is therefore likely that mutations in other genes with similar functions are involved in the causation of Hürthle cell tumours of the thyroid, and they should also be considered candidate genes for mitochondrial-rich tumours of other sites.

Table 4 Summary of the data regarding ret/PTC rearrangements and B-RAF mutations in the four patients with GRIM- 19 mutations

\begin{tabular}{lclll}
\hline Case & Age (years) & Diagnosis & $\begin{array}{l}\text { B-RAF } \\
\text { mutation }\end{array}$ & $\begin{array}{l}\text { RET/PTC } \\
\text { rearrangements }\end{array}$ \\
\hline 4 & 42 & HCFC & Negative & Negative \\
5 & 60 & HCPC & Negative & Negative \\
6 & 33 & HCPC & Not done & Not done \\
7 & 32 & HCPC & Negative & Positive \\
\hline
\end{tabular}

HCFC $=$ Hürthle cell variant of follicular carcinoma, HCPC $=$ Hürthle cell variant of papillary carcinoma.

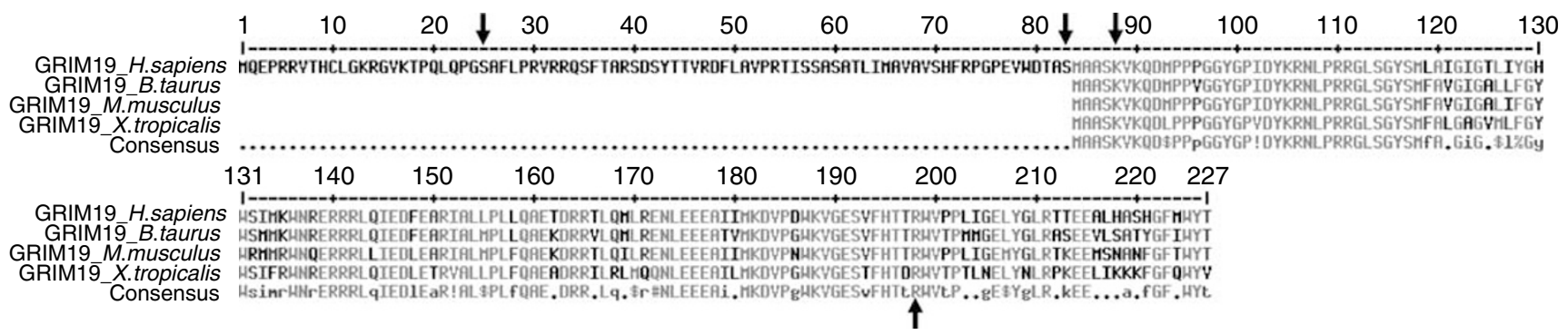

Figure 3 Alignment of the GRIM- 19 protein sequence in four species (Homo sapiens, Bos taurus, Mus musculus and Xenopus tropicalis; accession number: NP_057049, NP_788845, NP_07580 I and NP_988900, respectively). Arrows indicate the positions of the amino acids mutated in our series of Hürthle cell tumours (see Tab̆le 2). 
The major role of GRIM-19 in control of cell growth is exerted through STAT3, a transcription factor known to be inhibited by GRIM-19 binding (Lufei et al, 2003; Zhang et al, 2003). We have shown that the cases with GRIM-19 mutations display increased expression of the STAT3 regulated gene ICAM1; this finding fits with a loss of function of GRIM-19. Only two of the 22 cases without mutation in GRIM-19 gene showed a slightly elevated expression of the ICAM1 gene: the levels in these two cases were considerably lower $(P=0.07)$ than those detected in four cases with mutations and may reflect alterations in pathways other than STAT3 pathway.

The failure to detect $\mathrm{LOH}$ with the limited range of markers used does not exclude a tumorigenic role for GRIM19 mutations. Angell et al (2000) showed that downregulation of GRIM-19 was able to provide growth advantage, and cooperating mutations in one of the many other nuclear or mitochondrial genes with similar functions could also be important in this setting.

Ret/PTC rearrangements were initially reported to be restricted to conventional papillary thyroid carcinomas (Grieco et al, 1990). Later, Cheung et al (2000) demonstrated that ret/PTC rearrangements could also be detected in cases of Hürthle cell variant of papillary carcinoma, thus supporting the assumption that ret/PTC is specific for the papillary phenotype (Cheung et al, 2000; DeLellis et al, 2004). Chiappetta et al (2002) reported the presence of the rearrangement in both benign and malignant Hürthle thyroid tumours including follicular and papillary histotypes; this finding remains to be confirmed in other series. $B-R A F$ mutations have also been frequently detected in cases of Hürthle cell variant of papillary carcinoma (Trovisco et al, 2004), but not in other types of Hürthle cell tumour (Kimura et al, 2003; Soares et al, 2003). In order to verify if the GRIM-19 mutation may cooperate with those genetic events in Hürthle cell tumours, we have searched for them in GRIM-19-positive cases. The detection of a ret/PTC-1 rearrangement in Case 7 (Hürthle cell variant of papillary carcinoma) suggests that GRIM-19 mutation may serve as a predisposing alteration for the occurrence of tumours with cell oxyphilia. Other alterations, such as ret/PTC rearrangement or $B-R A F$ mutation, may be necessary for the acquisition of the malignant phenotype, as in non-Hürthle cell papillary carcinomas (Grieco et al, 1990; Soares et al, 1998, 2003; Sugg et al, 1998; Cohen et al, 2003; Kimura et al, 2003).

The autosomal dominant inheritance of Hürthle cell tumours has been described in a single family (Canzian et al, 1998). A separate study of a large number of thyroidectomies for Hürthle cell tumours found that about $20 \%$ of cases showed multiple separate Hürthle cell tumours, and that these were significantly younger and much more often female than the solitary tumours (Katoh et al, 1998). No mutations were detected in any of the five exons, nor in the respective intronic boundaries of GRIM-19 in the six cases from two Hürthle cell tumour families. Since four of these cases belonged to the family described by Canzian et al (1998), our results do not support the identification of GRIM-19 as the TCO gene mapped to chromosome 19p13.2 by those authors (Canzian et al, 1998).

The observation that the only germline mutation in GRIM-19 found in well over 100 samples tested was in the one patient with multiple Hürthle cell tumours suggests that this gene could account for some cases with a low penetrance pattern of inheritance. The absence of identifiable lesions in the patient's son who also carried the mutated gene is not surprising in view of his younger age (41 vs 60 years) and the rarity of multiple Hürthle cell tumours in males (Katoh et al, 1998).

Proof that a particular mutation is oncogenic requires both the demonstration of its presence in tumours, and the demonstration that the mutated gene confers an oncogenic advantage. We have shown that mutations in GRIM-19 are associated with a specific subtype of thyroid tumours, and each of the four mutations we found led to amino-acid substitutions. Downregulation of GRIM19 has been shown to confer a growth advantage on cells and to reduce the likelihood that they will enter apoptosis (Angell et al, 2000). We therefore believe that GRIM-19 mutations can make a significant contribution to the tumorigenic process in Hürthle cell tumours of the thyroid. Further in vitro studies are needed to demonstrate directly that the mutations we have found lead to downregulation of GRIM-19 function.

\section{ACKNOWLEDGEMENTS}

The authors thank Dr Pierre Levillain for having provided material from a series of four cases from a family with familial Hürthle cell tumours with linkage to chromosome 19p13.2. This study was partially supported by two PhD Grants (PRAXIS XXI/BD/21795/99 - AP, SFRH/BD/8425/2002 - JL) and by a Post-Doc Grant (SFRH/ BPD/14594/2003 - VM) from the Portuguese Science and Technology Foundation (FCT), and by further funding from the same source (Project - POCT/41055/NSE/2001).

\section{REFERENCES}

Angell JE, Lindner DJ, Shapiro PS, Hofmann ER, Kalvakolanu DV (2000) Identification of GRIM-19, a novel cell death-regulatory gene induced by the interferon-beta and retinoic acid combination, using a genetic approach. J Biol Chem 275: 33416-33426

Attardi G, Yoneda M, Chomyn A (1995) Complementation and segregation behavior of disease-causing mitochondrial DNA mutations in cellular model systems. Biochim Biophys Acta 1271: $241-248$

Bromberg JF, Wrzeszczynska MH, Devgan G, Zhao Y, Pestell RG, Albanese C, Darnell Jr JE (1999) Stat3 as an oncogene. Cell 98: $295-303$

Caldenhoven E, van Dijk TB, Solari R, Armstrong J, Raaijmakers JA, Lammers JW, Koenderman L, de Groot RP (1996) STAT3beta, a splice variant of transcription factor STAT3, is a dominant negative regulator of transcription. J Biol Chem 271: 13221 - 13227

Cantwell CA, Sterneck E, Johnson PF (1998) Interleukin-6-specific activation of the C/EBPdelta gene in hepatocytes is mediated by Stat3 and Sp1. Mol Cell Biol 18: 2108-2117

Canzian F, Amati P, Harach HR, Kraimps JL, Lesueur F, Barbier J, Levillain P, Romeo G, Bonneau D (1998) A gene predisposing to familial thyroid tumors with cell oxyphilia maps to chromosome 19p13.2. Am J Hum Genet 63: $1743-1748$
Cheung CC, Ezzat S, Ramyar L, Freeman JL, Asa SL (2000) Molecular basis of Hürthle cell papillary thyroid carcinoma. J Clin Endocrinol Metab 85: $878-882$

Chiappetta G, Toti P, Cetta F, Giuliano A, Pentimalli F, Amendola I, Lazzi S, Monaco M, Mazzuchelli L, Tosi P, Santoro M, Fusco A (2002) The RET/ PTC oncogene is frequently activated in oncocytic thyroid tumors (Hürthle cell adenomas and carcinomas), but not in oncocytic hyperplastic lesions. J Clin Endocrinol Metab 87: 364-369

Chidambaram NV, Angell JE, Ling W, Hofmann ER, Kalvakolanu DV (2000) Chromosomal localization of human GRIM-19, a novel IFN-beta and retinoic acid-activated regulator of cell death. J Interferon Cytokine Res 20: 661-665

Chin YE, Kitagawa M, Su WC, You ZH, Iwamoto Y, Fu XY (1996) Cell growth arrest and induction of cyclin-dependent kinase inhibitor p21 WAF1/CIP1 mediated by STAT1. Science 272: 719-722

Cohen Y, Xing M, Mambo E, Guo Z, Wu G, Trink B, Beller U, Westra WH, Ladenson PW, Sidransky D (2003) BRAF mutation in papillary thyroid carcinoma. J Natl Cancer Inst 95: 625-627

Darnell Jr JE, Kerr IM, Stark GR (1994) Jak-STAT pathways and transcriptional activation in response to IFNs and other extracellular signaling proteins. Science 264: 1415-1421 
Davies H, Bignell GR, Cox C, Stephens P, Edkins S, Clegg S, Teague J, Woffendin H, Garnett MJ, Bottomley W, Davis N, Dicks E, Ewing R, Floyd Y, Gray K, Hall S, Hawes R, Hughes J, Kosmidou V, Menzies A, Mould C, Parker A, Stevens C, Watt S, Hooper S, Wilson R, Jayatilake H, Gusterson BA, Cooper C, Shipley J, Hargrave D, Pritchard-Jones K, Maitland N, Chenevix-Trench G, Riggins GJ, Bigner DD, Palmieri G, Cossu A, Flanagan A, Nicholson A, Ho JW, Leung SY, Yuen ST, Weber BL, Seigler HF, Darrow TL, Paterson H, Marais R, Marshall CJ, Wooster R, Stratton MR, Futreal PA (2002) Mutations of the BRAF gene in human cancer. Nature 417: 949-954

DeLellis RA, Lloyd RV, Heitz PU, Eng C (2004) World Health Organization Classification of Tumours. Pathology and Genetics of Tumours of Endocrine Organs. Lyon: IARC Press

Farrand K, Delahunt B, Wang XL, McIver B, Hay ID, Goellner JR, Eberhardt NL, Grebe SK (2002) High resolution loss of heterozygosity mapping of 17 p13 in thyroid cancer: Hurthle cell carcinomas exhibit a small 411kilobase common region of allelic imbalance, probably containing a novel tumor suppressor gene. J Clin Endocrinol Metab 87: 4715-4721

Fearnley IM, Carroll J, Shannon RJ, Runswick MJ, Walker JE, Hirst J (2001) GRIM-19, a cell death regulatory gene product, is a subunit of bovine mitochondrial NADH:ubiquinone oxidoreductase (complex I). J Biol Chem 276: $38345-38348$

Finn SP, Smyth P, O'Leary J, Sweeney EC, Sheils O (2003) Ret/PTC chimeric transcripts in an Irish cohort of sporadic papillary thyroid carcinoma. J Clin Endocrinol Metab 88: 938-941

Fukada T, Ohtani T, Yoshida Y, Shirogane T, Nishida K, Nakajima K, Hibi M, Hirano T (1998) STAT3 orchestrates contradictory signals in cytokine-induced G1 to S cell-cycle transition. EMBO J 17: 6670 - 6677

Grandis JR, Drenning SD, Zeng Q, Watkins SC, Melhem MF, Endo S, Johnson DE, Huang L, He Y, Kim JD (2000) Constitutive activation of Stat3 signaling abrogates apoptosis in squamous cell carcinogenesis in vivo. Proc Natl Acad Sci USA 97: 4227-4232

Grieco M, Santoro M, Berlingieri MT, Melillo RM, Donghi R, Bongarzone I, Pierotti MA, Della Porta G, Fusco A, Vecchio G (1990) PTC is a novel rearranged form of the ret proto-oncogene and is frequently detected in vivo in human thyroid papillary carcinomas. Cell 60: 557-563

Hamperl H (1962) Benign and malignant oncocytoma. Cancer 15: 1019 1027

Hofmann ER, Boyanapalli M, Lindner DJ, Weihua X, Hassel BA, Jagus R, Gutierrez PL, Kalvakolanu DV, Hofman ER (1998) Thioredoxin reductase mediates cell death effects of the combination of beta interferon and retinoic acid. Mol Cell Biol 18: 6493-6504

Huang G, Lu H, Hao A, Ng DC, Ponniah S, Guo K, Lufei C, Zeng Q, Cao X (2004) GRIM-19, a cell death regulatory protein, is essential for assembly and function of mitochondrial complex I. Mol Cell Biol 24: 8447-8456

Hwang JH, Kim DW, Suh JM, Kim H, Song JH, Hwang ES, Park KC, Chung HK, Kim JM, Lee TH, Yu DY, Shong M (2003) Activation of signal transducer and activator of transcription 3 by oncogenic RET/PTC (rearranged in transformation/papillary thyroid carcinoma) tyrosine kinase: roles in specific gene regulation and cellular transformation. $\mathrm{Mol}$ Endocrinol 17: 1155-1166

Katoh R, Harach HR, Williams ED (1998) Solitary, multiple, and familial oxyphil tumours of the thyroid gland. J Pathol 186: 292-299

Kimura ET, Nikiforova MN, Zhu Z, Knauf JA, Nikiforov YE, Fagin JA (2003) High prevalence of BRAF mutations in thyroid cancer: genetic evidence for constitutive activation of the RET/PTC-RAS-BRAF signaling pathway in papillary thyroid carcinoma. Cancer Res 63: 1454-1457

Li LY, Luo X, Wang X (2001) Endonuclease G is an apoptotic DNase when released from mitochondria. Nature 412: 95 - 99
Liu X, Kim CN, Yang J, Jemmerson R, Wang X (1996) Induction of apoptotic program in cell-free extracts: requirement for dATP and cytochrome $c$. Cell 86: $147-157$

Lufei C, Ma J, Huang G, Zhang T, Novotny-Diermayr V, Ong CT, Cao X (2003) GRIM-19, a death-regulatory gene product, suppresses Stat3 activity via functional interaction. EMBO J 22: $1325-1335$

Máximo V, Soares P, Lima J, Cameselle-Teijeiro J, Sobrinho-Simões M (2002) Mitochondrial DNA somatic mutations (point mutations and large deletions) and mitochondrial DNA variants in human thyroid pathology: a study with emphasis on Hurthle cell tumors. Am J Pathol 160: $1857-1865$

Máximo V, Sobrinho-Simões M (2000a) Hurthle cell tumours of the thyroid. A review with emphasis on mitochondrial abnormalities with clinical relevance. Virchows Arch 437: 107-115

Máximo V, Sobrinho-Simões M (2000b) Mitochondrial DNA 'common' deletion in Hurthle cell lesions of the thyroid. J Pathol 192: 561-562

Nesland JM, Sobrinho-Simões M, Holm R, Sambade MC, Johannessen JV (1985) Hurthle-cell lesions of the thyroid: a combined study using transmission electron microscopy, scanning electron microscopy, and immunocytochemistry. Ultrastruct Pathol 8: 269-290

Niu G, Wright KL, Huang M, Song L, Haura E, Turkson J, Zhang S, Wang T, Sinibaldi D, Coppola D, Heller R, Ellis LM, Karras J, Bromberg J, Pardoll $\mathrm{D}$, Jove R, Yu H (2002) Constitutive Stat3 activity up-regulates VEGF expression and tumor angiogenesis. Oncogene 21: 2000-2008

Rosai J, Carcangiu ML, DeLellis RA (1992) Tumours of the thyroid gland. In Atlas of Tumour Pathology 3rd series, Armed Forces Institute of Pathology (ed). Washington: Armed Forces Institute of Pathology

Soares P, Fonseca E, Wynford-Thomas D, Sobrinho-Simões M (1998) Sporadic ret-rearranged papillary carcinoma of the thyroid: a subset of slow growing, less aggressive thyroid neoplasms? J Pathol 185: $71-78$

Soares P, Trovisco V, Rocha AS, Lima J, Castro P, Preto A, Máximo V, Botelho T, Seruca R, Sobrinho-Simões M (2003) BRAF mutations and RET/PTC rearrangements are alternative events in the etiopathogenesis of PTC. Oncogene 22: 4578-4580

Sobrinho-Simões M (1995) Tumours of thyroid: a brief overview with emphasis on the most controversial issues. Curr Diag Pathol 2: 15-22

Sobrinho-Simões M, Nesland JM, Holm R, Sambade MC, Johannessen JV (1985) Hurthle-cell lesions of the thyroid: a combined study using transmission electron microscopy, scanning electron microscopy, and immunocytochemistry. Ultrastruct Pathol 8: 131-142

Sugg SL, Ezzat S, Rosen IB, Freeman JL, Asa SL (1998) Distinct multiple RET/PTC gene rearrangements in multifocal papillary thyroid neoplasia. J Clin Endocrinol Metab 83: 4116-4122

Tallini G, Ladanyi M, Rosai J, Jhanwar SC (1994) Analysis of nuclear and mitochondrial DNA alterations in thyroid and renal oncocytic tumors. Cytogenet Cell Genet 66: 253-259

Trovisco V, Vieira de Castro I, Soares P, Maximo V, Silva P, Magalhaes J, Abrosimov A, Guiu XM, Sobrinho-Simoes M (2004) BRAF mutations are associated with some histological types of papillary thyroid carcinoma. J Pathol 202: 247-251

Yeh JJ, Lunetta KL, van Orsouw NJ, Moore Jr FD, Mutter GL, Vijg J, Dahia PL, Eng C (2000) Somatic mitochondrial DNA (mtDNA) mutations in papillary thyroid carcinomas and differential mtDNA sequence variants in cases with thyroid tumours. Oncogene 19: 2060-2066

Zhang J, Yang J, Roy SK, Tininini S, Hu J, Bromberg JF, Poli V, Stark GR, Kalvakolanu DV (2003) The cell death regulator GRIM-19 is an inhibitor of signal transducer and activator of transcription 3. Proc Natl Acad Sci USA 100: $9342-9347$ 